\title{
Quantitative Structure-Cytotoxicity Relationship of 2-Arylazolylchromones and 2-Triazolylchromones
}

\author{
JUNKO NAGAI ${ }^{1}$, HAIXIA SHI ${ }^{2,3}$, NATSUKO SEZAKI ${ }^{4}$, NAO YOSHIDA $^{4}$, \\ KENJIRO BANDOW $^{5}$, YOSHIHIRO UESAWA ${ }^{1 *}$, HIROSHI SAKAGAMI ${ }^{2}$, \\ MINEKO TOMOMURA ${ }^{6}$, AKITO TOMOMURA ${ }^{5}$, KOICHI TAKAO ${ }^{4}$ and YOSHIAKI SUGITA ${ }^{4}$ \\ ${ }^{1}$ Department of Medical Molecular Informatics, Meiji Pharmaceutical University, Tokyo, Japan; \\ ${ }^{2}$ Shanghai Ninth People's Hospital, Shanghai Jiatong University School of Medicine, Shanghai, P.R. China; \\ ${ }^{3}$ Meikai University Research Institute of Odontology, Sakado, Japan; \\ ${ }^{4}$ Department of Pharmaceutical Sciences, Faculty of Pharmacy and \\ Pharmaceutical Sciences, Josai University, Sakado, Japan; \\ ${ }^{5}$ Division of Biochemistry, Meikai University School of Dentistry, Sakado, Japan; \\ ${ }^{6}$ Department of Oral Health Sciences, Meikai University, Urayasu, Japan
}

\begin{abstract}
Background/Aim: 4H-1-Benzopyran-4-one (chromone), present in various flavonoids as a backbone structure, has been used for the synthesis of anticancer drugs. The study aimed at investigating the cytotoxicity of eight 2arylazolylchromones and twelve 2-triazolylchromones against four human oral squamous cell carcinoma (OSCC) cell lines and three human normal mesenchymal oral cells, and then performed a quantitative structure-activity relationship (QSAR) analysis. Materials and Methods: Cell viability was determined by the 3-(4,5-dimethylthiazol-2-yl)-2,5-diphenyltetrazolium bromide method. The distribution of cells to various phases of cell cycle was determined by cell cycle analysis. A total of 3,218 physicochemical, structural and quantum chemical features were calculated for QSAR analysis from the most stabilized structure optimized using CORINA. Results: 2-[4-(4fluorophenyl)-1H-imidazol-1-yl]-4H-1-benzopyran-4-one [6] had the highest tumor-specificity (TS), comparable with that of 5-flurouracil (5-FU) and doxorubicin, inducing cytostatic growth inhibition, accumulation of $G_{2}+M$ phase cells with no cells in the $G_{1}$ phase. All eight 2-triazolylchromones showed much lower tumor-specificity, confirming our previous finding. Tumor-specificity was also correlated with $3 D$ shape,
\end{abstract}

This article is freely accessible online.

Correspondence to: Yoshihiro Uesawa, Department of Medical Molecular Informatics, Meiji Pharmaceutical University, 2-522-1 Noshio, Kiyose, Tokyo 204-858, Japan. Tel: +81 424958892, e-mail: uesawa@my-pharm.ac.jp

Key Words: 2-Arylazolylchromones, 2-triazolylchromones, cytotoxicity, tumor-selectivity, QSAR analysis, cell cycle analysis, molecular shape. topological shape, size, ionization potential, and the presence of more than two aromatic rings in the molecule and imidazole ring in the nitrogen-containing heterocyclic ring. Conclusion: [6] can be a lead compound for designing anticancer drugs.

To develop new anticancer drugs, we have first established an in vitro screening system with four oral squamous cell carcinoma (OSCC) cell lines (Ca9-22, HSC-2, HSC-3, HSC-4) and three human oral normal mesenchymal cells (gingival fibroblast HGF, periodontal ligament fibroblast HPLF, pulp cell HPC) (1). Our large-scale in vitro screening of the antitumor activity of natural polyphenols such as tannins, flavonoids and antioxidants has demonstrated, surprisingly, lower tumor-specificity of most of these low molecular weight substances as compared with anticancer drugs (1). However, 4H-1-benzopyran-4-one (chromone), present in various flavonoids as a backbone structure, has been used for the synthesis of new types of anticancer drugs (2). Novel cytotoxic agents based on chromen4-one and chromane-2,4-dione scaffolds (3), chrysin derivatives (4) and $O$-alkyl derivatives of naringenin and their oximes (5) have been synthesized, however, their tumor-specificity has not been described. We have synthesized 16 groups of chemically modified derivatives (239 compounds) $(6,7)$. We have found that 3-styrylchromones (8), 3-styryl- $2 H$-chromenes (9) and 2azolylchromones, especially, three sets of 4H-1-benzopyran-4ones with indole ring (10) had comparable tumor-specificity and lower cytotoxicity against human oral keratinocytes (human oral mucosal keratinocyte $\mathrm{HOK}$, primary human gingival epithelial cells HGEP), as compared with common anticancer drugs (11).

As far as we know, only two studies from our groups have reported the biological activity of azolylchromone $(10,12)$. In order to perform quantitative structure-activity relationship (QSAR) analysis, we investigated the tumor-specificity of 


\section{2-Arylazolylchromones (1-8)}<smiles>O=c1cc(-n2ccc(-c3ccccc3)n2)oc2ccccc12</smiles><smiles>[R2][R]#[R]c1cc(=O)c2cc([R])c([R])cc2o1</smiles>

3: $R^{1}=O M e, R^{2}=H$

4: $\mathrm{R}^{1}=\mathrm{H}, \mathrm{R}^{2}=\mathrm{OMe}$<smiles>[R1][R1]([H])(F)[R](F)(F)Cl</smiles><smiles>O=c1cc(-n2cnc(-c3ccccc3)c2-c2ccccc2)oc2ccccc12</smiles>

\section{2-Triazolylchromones (9-20)}<smiles>[R]c1nc([R])n(-c2cc(=O)c3cc([R])c([R])cc3o2)n1</smiles>

\begin{tabular}{cllll}
\hline Compound & $\mathrm{R}^{1}$ & $\mathrm{R}^{2}$ & $\mathrm{R}^{3}$ & $\mathrm{R}^{4}$ \\
\hline 9 & $\mathrm{H}$ & $\mathrm{H}$ & $\mathrm{H}$ & $\mathrm{H}$ \\
10 & $\mathrm{OCH}_{3}$ & $\mathrm{H}$ & $\mathrm{H}$ & $\mathrm{H}$ \\
11 & $\mathrm{H}$ & $\mathrm{OCH}_{3}$ & $\mathrm{H}$ & $\mathrm{H}$ \\
12 & $\mathrm{Cl}$ & $\mathrm{H}$ & $\mathrm{H}$ & $\mathrm{H}$ \\
13 & $\mathrm{H}$ & $\mathrm{H}$ & $\mathrm{CH}_{3}$ & $\mathrm{H}$ \\
14 & $\mathrm{OCH}_{3}$ & $\mathrm{H}$ & $\mathrm{CH}_{3}$ & $\mathrm{H}$ \\
15 & $\mathrm{H}$ & $\mathrm{OCH}_{3}$ & $\mathrm{CH}_{3}$ & $\mathrm{H}$ \\
16 & $\mathrm{Cl}$ & $\mathrm{H}$ & $\mathrm{CH}_{3}$ & $\mathrm{H}$ \\
17 & $\mathrm{H}$ & $\mathrm{H}$ & $\mathrm{CH}_{3}$ & $\mathrm{CH}_{3}$ \\
18 & $\mathrm{OCH}_{3}$ & $\mathrm{H}$ & $\mathrm{CH}_{3}$ & $\mathrm{CH}_{3}$ \\
19 & $\mathrm{H}$ & $\mathrm{OCH}_{3}$ & $\mathrm{CH}_{3}$ & $\mathrm{CH}_{3}$ \\
20 & $\mathrm{Cl}$ & $\mathrm{H}$ & $\mathrm{CH}_{3}$ & $\mathrm{CH}_{3}$ \\
\hline
\end{tabular}

2-[3-(2-pyridinyl)-1H-pyrazol-1-yl]-4H-1-benzopyran-4-one [3], 7 methoxy-2-[3-(2-pyridinyl)-1 $H$-pyrazol-1-yl]-4H-1-benzopyran-4-one [4], 2-(4-phenyl-1H-imidazol-1-yl)-4H-1-benzopyran-4-one [5], 2-[4(4-fluorophenyl)-1 $H$-imidazol-1-yl]-4H-1-benzopyran-4-one [6], 2-[4(4-chlorophenyl)-1 $H$-imidazol-1-yl]-4H-1-benzopyran-4-one [7], 2(4,5-diphenyl-1 $H$-imidazol-1-yl)-4H-1-benzopyran-4-one [8], 2-(1H1,2,4-triazol-1-yl)-4H-1-benzopyran-4-one [9], 6-methoxy-2-(1H1,2,4-triazol-1-yl)-4H-1-benzopyran-4-one [10], 7-methoxy-2-(1H1,2,4-triazol-1-yl)-4H-1-benzopyran-4-one [11], 6-chloro-2-( $1 H-1,2,4-$ triazol-1-yl)-4H-1-benzopyran-4-one [12], 2-(3-methyl- $1 H-1,2,4-$ triazol-1-yl)-4H-1-benzopyran-4-one [13], 6-methoxy-2-(3-methyl-1H1,2,4-triazol-1-yl)-4H-1-benzopyran-4-one [14], 7-methoxy-2-(3methyl-1H-1,2,4-triazol-1-yl)-4H-1-benzopyran-4-one [15], 6-chloro2-(3-methyl-1 $H$-1,2,4-triazol-1-yl)-4H-1-benzopyran-4-one [16], 2 (3,5-dimethyl-1 $H-1,2,4$-triazol-1-yl)-4H-1-benzopyran-4-one [17], 2 (3,5-dimethyl-1 $H$-1,2,4-triazol-1-yl)-6-methoxy-4H-1-benzopyran-4one [18], 2-(3,5-dimethyl- $1 H$-1,2,4-triazol-1-yl)-7-methoxy-4H-1benzopyran-4-one [19] and 6-chloro-2-(3,5-dimethyl-1 $\mathrm{H}$-1,2,4-triazol1-yl)-4H-1-benzopyran-4-one [20] (Figure 1) were synthesized by the conjugated addition reactions of 3-iodochromone derivatives with selected azoles, as described previously (12). All compounds were dissolved in DMSO at $40 \mathrm{mM}$ and stored at $-20^{\circ} \mathrm{C}$ before use. 
Table I. Cytotoxic activity of the eight 2-arylazolylchromones and the twelve 2-triazolylchromones against oral malignant and non-malignant cells. Each value represents the mean of triplicate determinations. The tumor-specificity index (TS) and potency-selectivity expression (PSE) values were determined using human oral squamous cell carcinoma (OSCC) cell lines compared with human normal oral mesenchymal cells, and paired cells derived from the same (gingival) tissue.

\begin{tabular}{|c|c|c|c|c|c|c|c|c|c|c|c|c|c|c|c|}
\hline & \multicolumn{11}{|c|}{$\mathrm{CC}_{50}(\mu \mathrm{M})$} & \multirow{3}{*}{\multicolumn{2}{|c|}{ TS }} & \multirow{3}{*}{\multicolumn{2}{|c|}{ PSE }} \\
\hline & \multicolumn{6}{|c|}{ Human oral squamous cell carcinoma cell lines } & \multicolumn{5}{|c|}{ Human normal oral cells } & & & & \\
\hline & $\mathrm{Ca} 9-22$ & HSC-2 & HSC-3 & HSC-4 & Mean & SD & HGF & HPLF & HPC & Mean & SD & & & & \\
\hline & A & & & & B & & $\mathrm{C}$ & & & $\mathrm{D}$ & & $\mathrm{D} / \mathrm{B}$ & $\mathrm{C} / \mathrm{A}$ & $\begin{array}{c}\left(\mathrm{D} / \mathrm{B}^{2}\right) \\
\times 100\end{array}$ & $\begin{array}{c}\left(\mathrm{C} / \mathrm{A}^{2}\right) \\
\times 100\end{array}$ \\
\hline \multicolumn{16}{|c|}{$<2$-Arylazolylchromones $>$} \\
\hline 1 & 18.2 & 7.4 & 15.2 & 18.4 & 14.8 & 5.2 & 56.3 & 29.6 & 9.6 & 31.8 & 23.4 & 2.2 & 3.1 & 14.5 & 17.0 \\
\hline 2 & 400.0 & 400.0 & 400.0 & 400.0 & 400.0 & 0.0 & 400.0 & 400.0 & 246.2 & 348.7 & 88.8 & 0.9 & 1.0 & 0.2 & 0.3 \\
\hline 3 & 400.0 & 400.0 & 400.0 & 400.0 & 400.0 & 0.0 & 400.0 & 400.0 & 400.0 & 400.0 & 0.0 & 1.0 & 1.0 & 0.3 & 0.3 \\
\hline 4 & 400.0 & 321.0 & 205.3 & 121.0 & 261.8 & 123.3 & 400.0 & 400.0 & 400.0 & 400.0 & 0.0 & 1.5 & 1.0 & 0.6 & 0.3 \\
\hline 5 & 8.4 & 4.0 & 7.3 & 6.4 & 6.5 & 1.9 & 19.5 & 27.0 & 20.4 & 22.3 & 4.1 & 3.4 & 2.3 & 52.1 & 27.4 \\
\hline 6 & 16.1 & 11.6 & 22.3 & 23.6 & 18.4 & 5.6 & 366.7 & 400.0 & 400.0 & 388.9 & 19.2 & 21.2 & 22.8 & 115.0 & 142.0 \\
\hline 7 & 37.3 & 34.9 & 272.0 & 400.0 & 186.1 & 180.9 & 400.0 & 400.0 & 400.0 & 400.0 & 0.0 & 2.1 & 10.7 & 1.2 & 28.7 \\
\hline 8 & 17.8 & 10.1 & 21.5 & 22.7 & 18.0 & 5.7 & 39.3 & 65.3 & 400.0 & 168.2 & 201.1 & 9.3 & 2.2 & 51.7 & 12.4 \\
\hline $5-\mathrm{FU}$ & 20.5 & 28.0 & 7.8 & 5.1 & 15.4 & 10.8 & 1000.0 & 1000.0 & 335.7 & 778.6 & 383.6 & 50.7 & 48.7 & 329.6 & 237.2 \\
\hline DXR & 0.18 & 0.08 & 0.08 & 0.08 & 0.10 & 0.05 & 10.00 & 10.00 & 0.20 & 6.73 & 5.66 & 64.9 & 56.1 & 62461.7 & 31443.8 \\
\hline \multicolumn{16}{|c|}{$<2$-Triazolylchromones $>$} \\
\hline 9 & 151.0 & 128.3 & 145.3 & 238.3 & 165.8 & 49.3 & 273.3 & 375.7 & 364.0 & 337.7 & 56.0 & 2.0 & 1.8 & 1.2 & 1.2 \\
\hline 10 & 149.7 & 111.3 & 167.7 & 105.3 & 133.5 & 30.1 & 362.3 & 332.7 & 358.7 & 351.2 & 16.2 & 2.6 & 2.4 & 2.0 & 1.6 \\
\hline 11 & 364.0 & 245.0 & 286.7 & 307.0 & 300.7 & 49.5 & 400.0 & 370.3 & 392.0 & 387.0 & 15.3 & 1.3 & 1.1 & 0.4 & 0.3 \\
\hline 12 & 57.8 & 52.2 & 84.9 & 66.7 & 65.4 & 14.3 & 134.0 & 212.0 & 171.7 & 172.6 & 39.0 & 2.6 & 2.3 & 4.0 & 4.0 \\
\hline 13 & 400.0 & 400.0 & 400.0 & 395.0 & 399.0 & 2.5 & 400.0 & 400.0 & 366.0 & 389.0 & 19.4 & 1.0 & 1.0 & 0.2 & 0.3 \\
\hline 14 & 400.0 & 400.0 & 371.0 & 343.0 & 379.0 & 27.3 & 25.1 & 400.0 & 387.0 & 271.0 & 212.8 & 0.7 & 0.1 & 0.2 & 0.0 \\
\hline 15 & 213.8 & 166.0 & 147.0 & 299.7 & 206.6 & 68.1 & 14.6 & 167.3 & 174.7 & 118.9 & 90.4 & 0.6 & 0.1 & 0.3 & 0.0 \\
\hline 16 & 322.3 & 400.0 & 291.0 & 317.7 & 333.0 & 46.9 & 400.0 & 374.7 & 355.7 & 377.0 & 22.2 & 1.1 & 1.2 & 0.3 & 0.4 \\
\hline 17 & 262.3 & 230.3 & 274.7 & 332.0 & 274.8 & 42.4 & 348.7 & 400.0 & 400.0 & 383.0 & 29.6 & 1.4 & 1.3 & 0.5 & 0.5 \\
\hline 18 & 271.7 & 187.7 & 145.7 & 266.7 & 217.9 & 61.6 & 400.0 & 400.0 & 400.0 & 400.0 & 0.0 & 1.8 & 1.5 & 0.8 & 0.5 \\
\hline 19 & 150.7 & 148.7 & 152.3 & 161.0 & 153.2 & 5.4 & 190.3 & 397.0 & 355.3 & 314.3 & 109.4 & 2.1 & 1.3 & 1.3 & 0.8 \\
\hline 20 & 131.0 & 142.3 & 129.7 & 206.0 & 152.3 & 36.3 & 280.3 & 400.0 & 377.0 & 352.4 & 63.5 & 2.3 & 2.1 & 1.5 & 1.6 \\
\hline $5-\mathrm{FU}$ & 22.9 & 20.7 & 19.5 & 7.8 & 17.7 & 6.8 & 1000.0 & 1000.0 & 1000.0 & 1000.0 & 0.0 & 56.4 & 43.6 & 318.0 & 190.1 \\
\hline DXR & 0.16 & 0.09 & 0.09 & 0.09 & 0.11 & 0.04 & 0.89 & 1.88 & 1.17 & 1.31 & 0.51 & 12.4 & 5.5 & 11689.5 & 3337.5 \\
\hline
\end{tabular}

DXR: Doxorubicin; 5-FU: 5-flurouracil; Ca9-22, derived from gingival tissue; HSC-2, HSC-3 and HSC-4, derived from the tongue. Compounds 1-20 are shown in bold.

Cell culture. Human normal oral mesenchymal cells (HGF, HPLF, HPC) (13) at 10-18 population doublings were used in this study. Human oral squamous cell carcinoma (OSCC) cell lines (Ca9-22, derived from gingival tissue; HSC-2, HSC-3 and HSC-4 derived from tongue) were purchased from Riken Cell Bank (Tsukuba, Japan). All cells were cultured at $37^{\circ} \mathrm{C}$ in DMEM supplemented with $10 \%$ heat-inactivated FBS, 100 units/ml, penicillin $\mathrm{G}$ and $100 \mu \mathrm{g} / \mathrm{ml}$ streptomycin sulfate under a humidified $5 \% \mathrm{CO}_{2}$ atmosphere. Cell morphology was examined periodically under a light microscope (EVOS FL; Thermo Fisher Scientific, Waltham, MA, USA).

Assay for cytotoxic activity. Cells were plated at $2 \times 10^{3}$ cells $/ 0.1 \mathrm{ml}$ in a 96-microwell plate. After $48 \mathrm{~h}$, the medium was replaced with
$0.1 \mathrm{ml}$ of fresh medium containing different concentrations of single test compounds. Cells were incubated for $48 \mathrm{~h}$ and the relative viable cell number was then determined in triplicate by the MTT method, as described previously (7-11). Control cells were treated with the same percentage of DMSO and the cell death induced by DMSO was subtracted. The concentration of compound that reduced the viable cell number by $50 \%\left(\mathrm{CC}_{50}\right)$ was determined from the dose-response curve.

Calculation of tumor-specificity index (TS). TS was calculated by dividing the mean $\mathrm{CC}_{50}$ against normal oral cell types by the mean $\mathrm{CC}_{50}$ against OSCC cell lines (D/B in Table I). Since both Ca9-22 and HGF cells were derived from gingival tissue (14), TS was also 


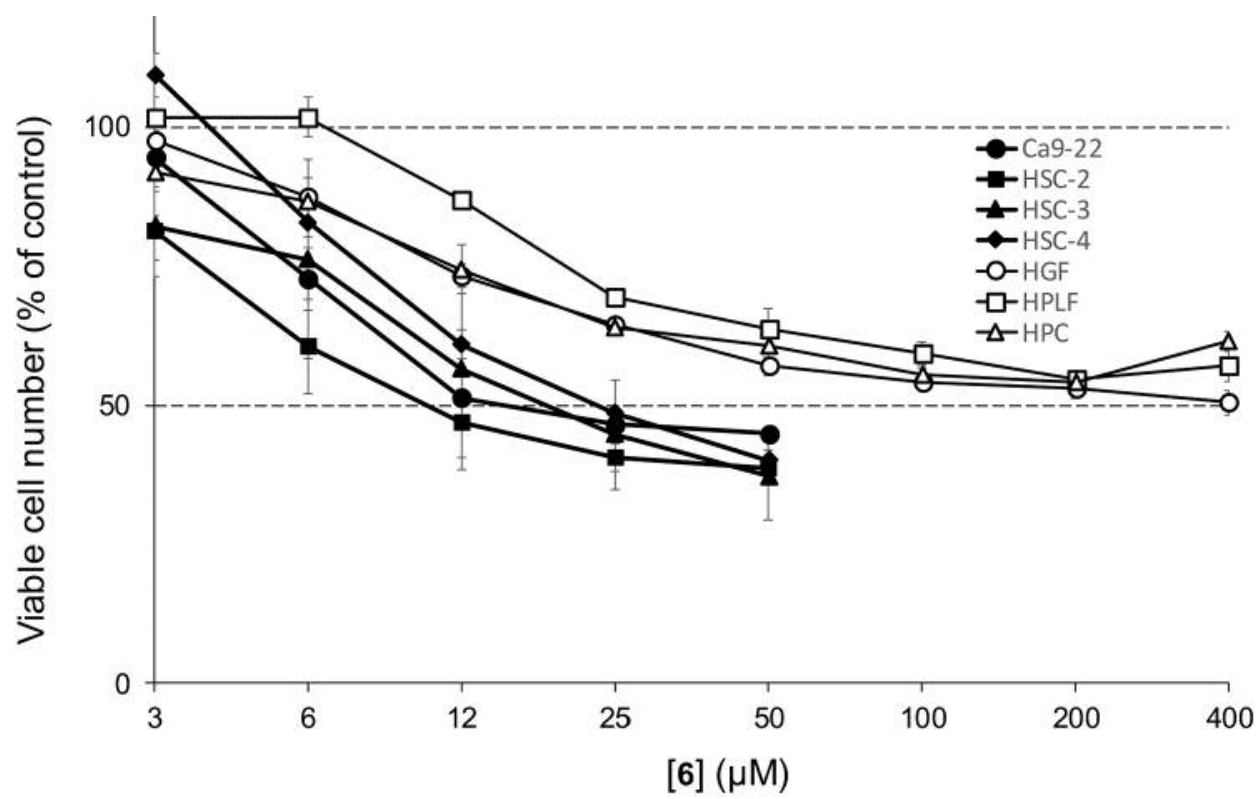

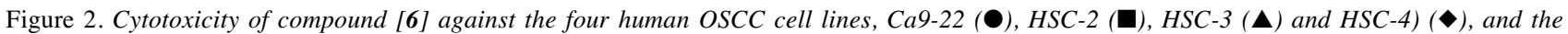
three human normal mesenchymal oral cells, HGF $(\bigcirc), H P L F(\square)$ and HPC $(\triangle)$. Cells were incubated for $48 \mathrm{~h}$ without (control) or with the indicated concentrations of [6], and cell viability was determined by MTT method, and expressed as a percentage of the control. Each value represents the mean \pm S.D. of triplicate assays.
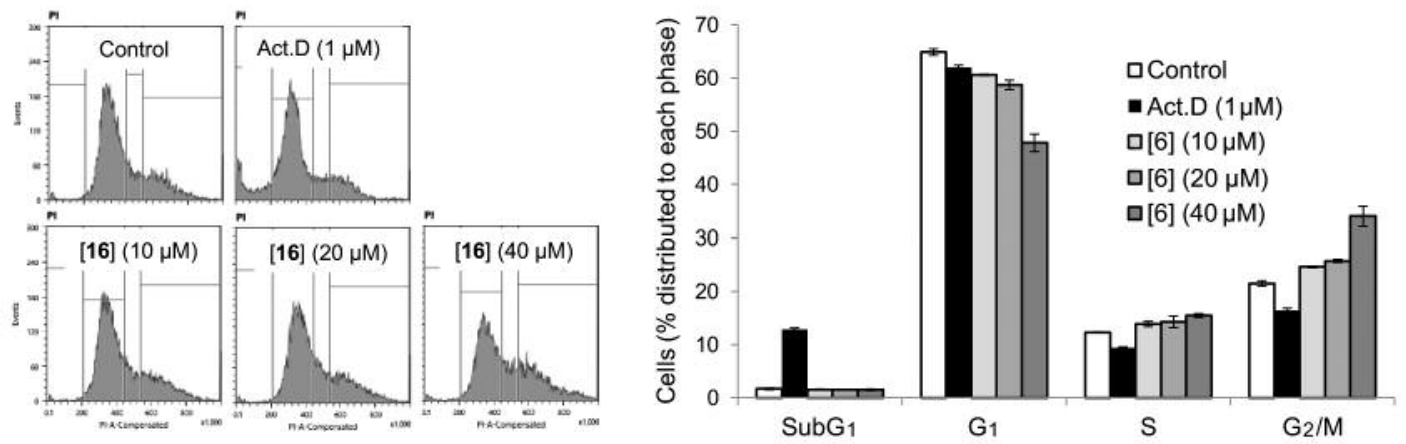

Figure 3. Effect of [6] on cell-cycle distribution in HSC-2 cells. HSC-2 cells were incubated for 24 h with the indicated concentrations of [6] or 1 $\mu M$ actinomycin $D($ Act $D)$ as positive control and then assessed for cell-cycle distribution by cell sorter.

calculated by dividing the $\mathrm{CC}_{50}$ against $\mathrm{HGF}$ by the mean $\mathrm{CC}_{50}$ against Ca9-22 (C/A in Table I).

Calculation of potency-selectivity expression (PSE). PSE was calculated by dividing the mean $\mathrm{CC}_{50}$ against normal oral cells by the (mean $\mathrm{CC}_{50}$ against OSCC cell lines) ${ }^{2}$ and then multiplied by 100 (in the case of HGF, HPLF, HPC vs. Ca9-22, HSC-2, HSC-3, HSC-4) $\left[\left(\mathrm{D} / \mathrm{B}^{2}\right) \times 100\right.$ in Table I]; and by dividing the $\mathrm{CC}_{50}$ against $\mathrm{HGF}$ by $\left(\mathrm{CC}_{50} \text { against } \mathrm{Ca} 9-22\right)^{2}$, and then multiplied by 100 (in the case of HGF vs. Ca9-22) [(C/A $\left.{ }^{2}\right) \times 100$ in Table I].

Cell-cycle analysis. Treated and untreated cells (approximately $10^{6}$ cells) were harvested, fixed with paraformaldehyde, treated with
RNase A, stained with PI in the presence of $0.01 \%$ NP-40, filtered through Falcon ${ }^{\circledR}$ cell strainers and then subjected to cell sorting (SH800 Series; SONY Imaging Products and Solutions Inc., Kanagawa, Japan) and cell-cycle analysis was performed using Cell Sorter Software version 2.1.2. (SONY Imaging Products and Solution Inc.), as described previously (15).

Estimation of $\mathrm{CC}_{50}$ values for computational analysis. Since the $\mathrm{CC}_{50}$ values had a distribution pattern close to the logarithmically normal distribution, we used the negative $\log \mathrm{CC}_{50}\left(\mathrm{pCC}_{50}\right)$ values for the comparison of cytotoxicity between compounds. The mean $\mathrm{pCC}_{50}$ values for normal cells and tumor cell lines were defined as 

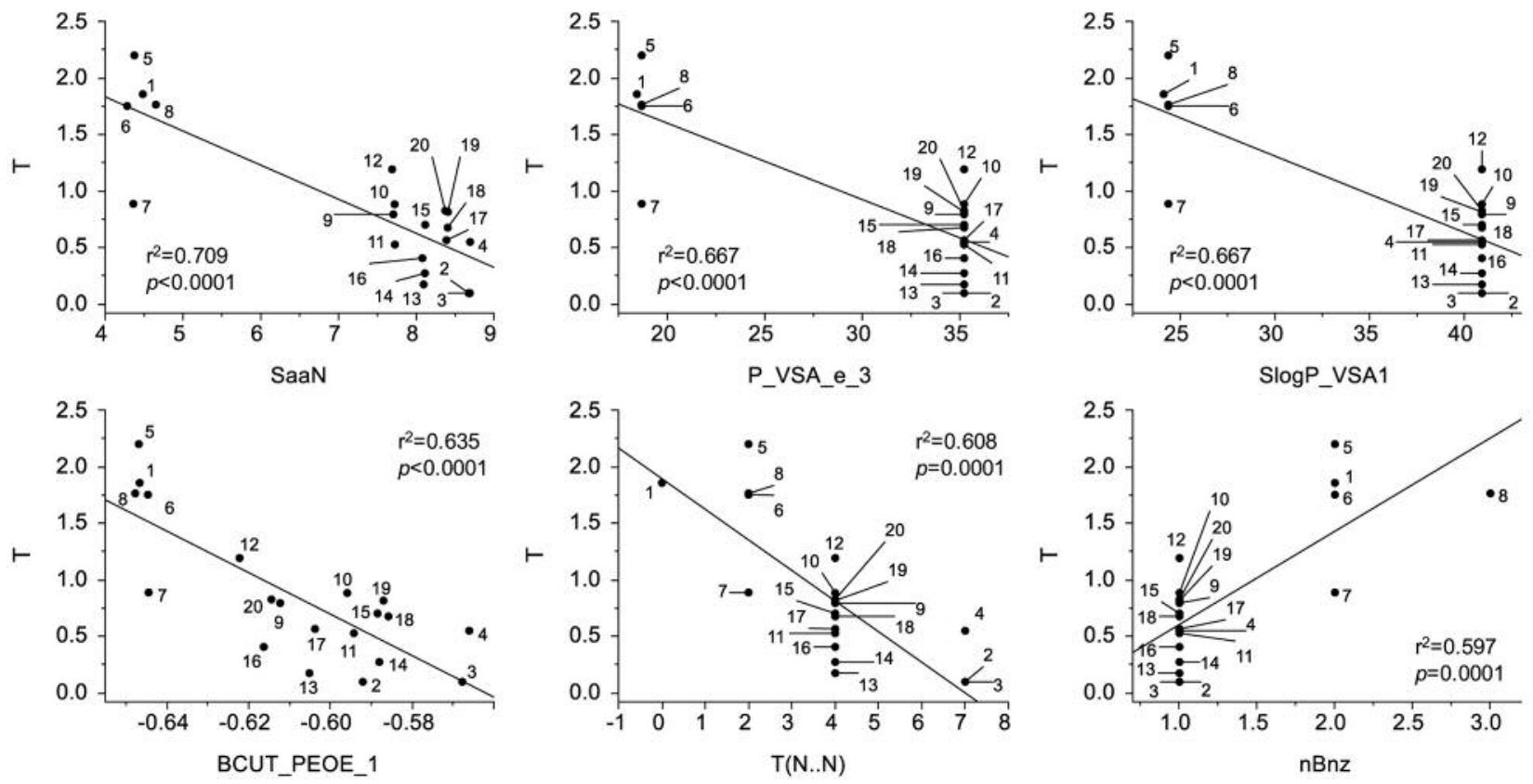

Figure 4. Top six chemical descriptors that showed higher correlation with cytotoxicity of eight 2-arylazolylchromones [1-8] and twelve 2triazolylchromones [9-20] against OSCC cells. The mean negative log $C_{50}$ values $(T)$ against tumor cells were plotted. CC $C_{50}$ : concentration of compound that reduced the viable cell number by 50\%. Top six chemical descriptors were: SaaN (topological shape and electric state), $P \_V S A \_e \_3$ (topological shape and electric state), SlogP_VSA1 (topological size and lipophilicity), BCUT_PEOE_1 (topological shape and partial charges), $T(N . . N)$ (topological shape and size) and nBnz (topological shape and size).
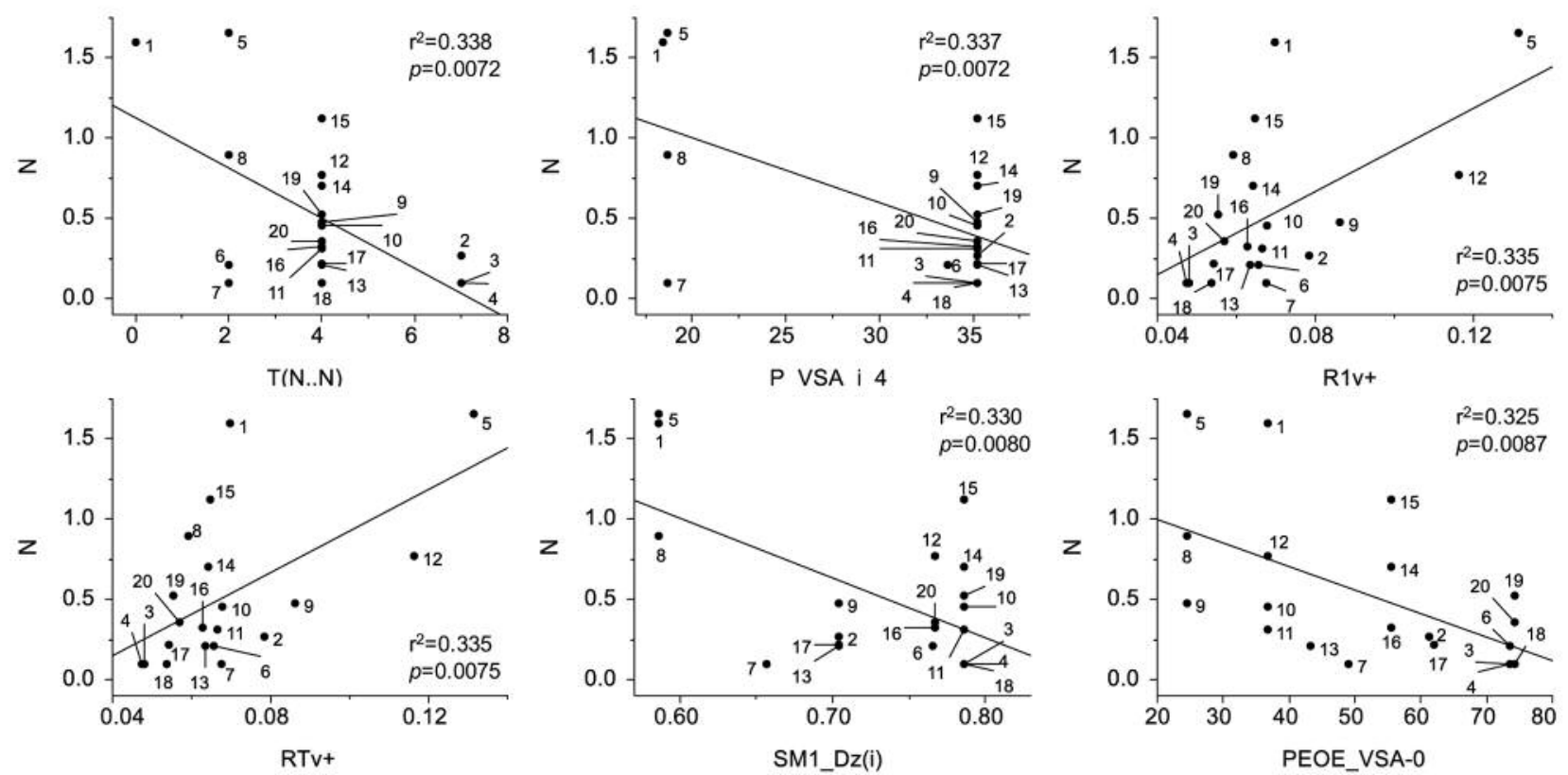

Figure 5. Top six chemical descriptors that showed higher correlation with cytotoxicity of eight 2-arylazolylchromones [1-8] and twelve 2triazolylchromones [9-20] against normal oral cells. The mean negative log $C_{50}$ values $(N)$ against normal cells were plotted. Top six chemical descriptors were: $T(N . . N)$ (topological shape and size), P_VSA_i_4 (topological shape and ionization potential), R1v+ (3D shape and size), RTv+ (3D shape and size), SM1_Dz(i) (topological shape, size and ionization potential), PEOE_VSA-O (topological shape and electric state). 

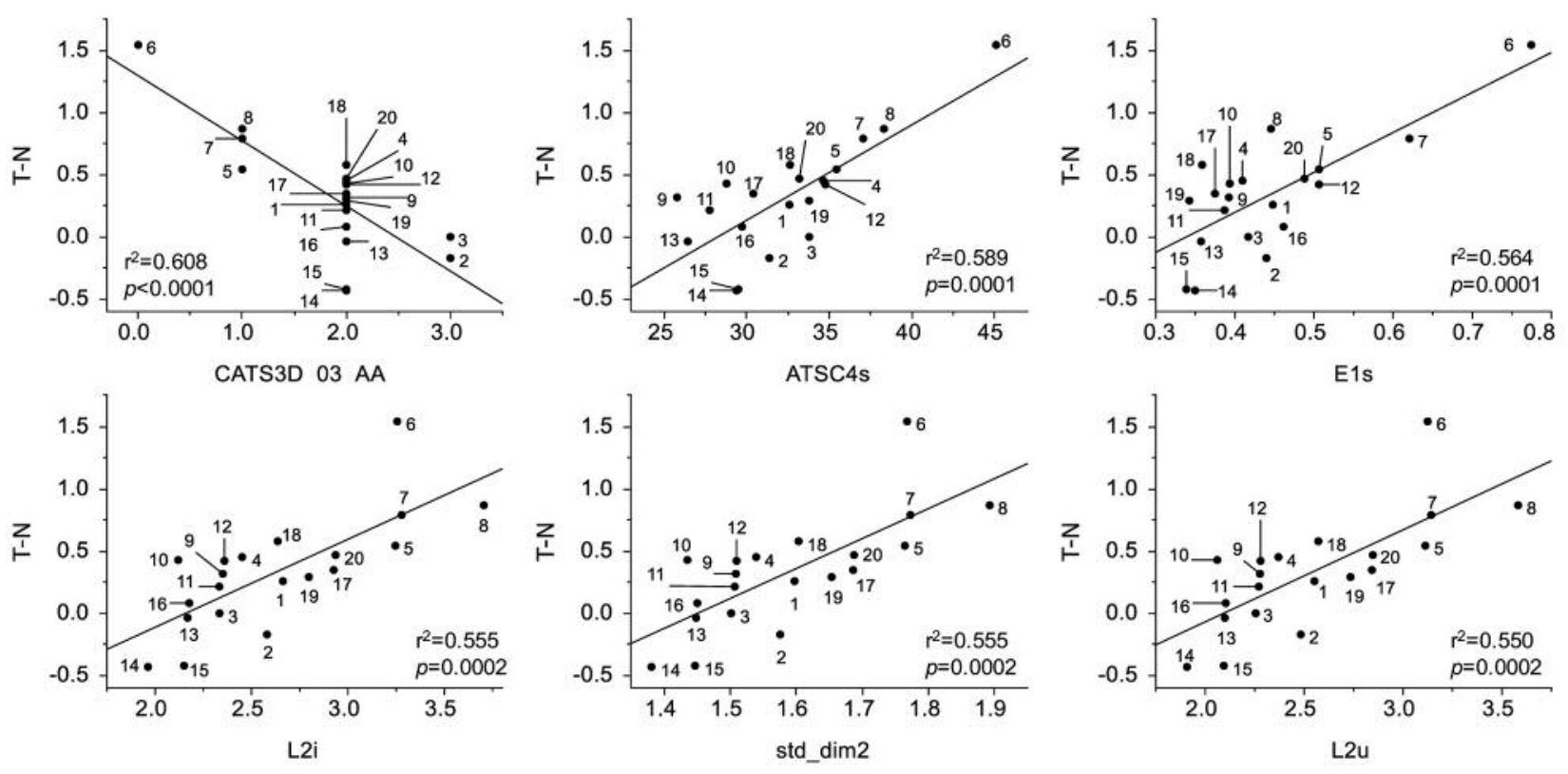

Figure 6. Top six chemical descriptors that showed higher correlation with tumor specificity of eight 2-arylazolylchromones [1-8] and twelve 2triazolylchromones [9-20]. The mean negative log TS values (T-N) were plotted. Top six chemical descriptors were: CATS3D_03_AA (3D shape and size), ATSC4s (topological shape and size), E1s (3D shape and size), L2i (3D shape, size and ionization potential), std_dim2 (3D shape) and L2u (3D shape and size).

$\mathrm{N}$ and $\mathrm{T}$, respectively. The difference $(\mathrm{T}-\mathrm{N})$ was used as a tumorspecificity index in the following analyses (8-10).

Calculation of chemical descriptors. The 3D structure of each chemical structure (Marvin Sketch ver 16; ChemAxon, Budapest, Hungary) (16), was optimized by CORINA Classic (Molecular Networks GmbH, Nürnberg, Germany) (17) with forcefield calculations (amber-10: EHT) in Molecular Operating Environment (MOE) version 2019.0101 (Chemical Computing Group Inc., Quebec, Canada) (18). The number of structural descriptors calculated from MOE and Dragon 7.0 (Dragon 7 version 7.0.2 (Kode srl., Pisa, Italy) (19) were 354 and 5,255, respectively. Among them, the number of descriptors used for analysis were 314 and 2,904 (total 3,218), respectively.

Statistical analysis. The $\mathrm{CC}_{50}$ values were expressed as mean \pm S.D. of triplicate assays. The relation among cytotoxicity, tumor-specificity index and chemical descriptors was investigated using simple regression analyses by JMP ${ }^{\circledR}$ Pro version 14.3.0 (SAS Institute Inc., Cary, NC, USA) (20). Statistical comparison between the means of two or three groups was performed by Wilcoxon exact test and SteelDwass test, respectively. The significance level was set at $p<0.05$.

\section{Results}

Cytotoxicity and tumor-specificity. Among eight 2arylazolylchromones, [5] showed the highest cytotoxicity against four OSCC cell lines (mean $\left.\mathrm{CC}_{50}=6.5 \mu \mathrm{M}\right)(\mathrm{B}$ in Table I), followed by [1] $(14.8 \mu \mathrm{M})>[\mathbf{8}](18.0 \mu \mathrm{M})>[$ 6] $(18.4 \mu \mathrm{M})$
$>$ [7] $(186.1 \mu \mathrm{M})>[4](261.8 \mu \mathrm{M})>[2,3](>400 \mu \mathrm{M})$. On the other hand, [5] showed the highest cytotoxicity against three normal oral mesenchymal cells (mean $\mathrm{CC}_{50}=22.3 \mu \mathrm{M}$ ) (D in Table I), followed by [1] $(31.8 \mu \mathrm{M})>$ [8] $(168.2 \mu \mathrm{M})>$ [2] $(348.7 \mu \mathrm{M})>[6](388.9 \mu \mathrm{M})>[3,4,7](>400 \mu \mathrm{M})$ (Table I). When tumor-specificity (TS) was calculated by the ratio of the mean $\mathrm{CC}_{50}$ for normal oral cells to that of OSCC cells (D/B in Table I), [6] showed the highest TS value (21.2), followed by [8] $(9.3)>[5](3.4)>[1](2.2)>[7](2.1)>[4]$ (1.5) $>[3](1.0)>[2](0.9)$. [6] also showed the highest PSE value $\left[\left(\mathrm{D} / \mathrm{B}^{2}\right) \times 100\right.$ in Table I] $(115.0)$, followed by [5] $(52.1)$ $>$ [8] (51.7) > [1] (14.5) > [7] (1.2) > [4] (0.6) > [3] (0.3) > [2] (0.2). The prominent TS and PSE values of [6] were not changed when the target cells were changed into Ca9-22 and HGF (both derived from gingival tissue): 22.8 (C/A) and 142. $\left[\left(\mathrm{C}^{2} \mathrm{~A}^{2}\right) \times 100\right.$ in Table I], respectively. The dose-response curve (Figure 2) demonstrated that [6] exerted cytostatic growth inhibition against all seven cells. It is apparent that all OSCC cells (Ca9-22, HSC-2, HSC-3, HSC-4) were more sensitive to [6] than the normal oral cells (HGF, HPLF, HPC). Cell-cycle analysis demonstrated that [6] did not affect the distribution of cells to $\operatorname{subG}_{1}$ phase but induced accumulation of cells in the $\mathrm{G}_{2}+\mathrm{M}$ phase cells (Figure 3 ).

The twelve 2-triazolylchromones [9-20] showed much lower TS [0.6 2.6 (D/B), 0.1 2.4 (C/A)] and PSE values $\left\{0.2 \sim 4.0\left[\left(\mathrm{D} / \mathrm{B}^{2}\right) \times 100\right], 0.02 \sim 4.0\left[\left(\mathrm{C} / \mathrm{A}^{2}\right) \times 100\right]\right\}($ Table I). 
Table II. Properties of descriptors that significantly correlated with cytotoxicity against tumor cells $(T)$ and normal cells $(N)$, and tumor-specificity $(T-N)$.

\begin{tabular}{|c|c|c|c|c|c|}
\hline & Descriptor & Source & Meaning & Category & Explanation \\
\hline \multirow[t]{6}{*}{$\mathrm{T}$} & SaaN & Dragon & Topological shape and electric state & Atom-type E-state indices & Sum of aaN E-states \\
\hline & P_VSA_e_3 & Dragon & Topological shape and electric state & P_VSA-like descriptor & $\begin{array}{l}\text { P_VSA-like on Sanderson } \\
\text { electronegativity, bin } 3\end{array}$ \\
\hline & SlogP_VSA1 & MOE & Topological size and lipophilicity & Subdivided Surface Areas & Sum of vi such that $\mathrm{Li}$ is in $(-0.4,-0.2]$. \\
\hline & BCUT_PEOE_1 & MOE & Topological shape and partial charges & $\begin{array}{l}\text { Adjacency and Distance } \\
\text { Matrix Descriptors }\end{array}$ & $\begin{array}{l}\text { The BCUT descriptors are calculated } \\
\text { from the eigenvalues of a modified } \\
\text { adjacency matrix. The diagonal takes } \\
\text { the value of the PEOE partial charges. }\end{array}$ \\
\hline & $\mathrm{T}(\mathrm{N} . . \mathrm{N})$ & Dragon & Topological shape and size & 2D Atom Pairs & $\begin{array}{c}\text { Sum of topological distances } \\
\text { between } \mathrm{N} . . \mathrm{N}\end{array}$ \\
\hline & $\mathrm{nBnz}$ & Dragon & Topological shape and size & Ring descriptors & Number of benzene-like rings \\
\hline \multirow[t]{6}{*}{$\mathrm{N}$} & $\mathrm{T}(\mathrm{N} . . \mathrm{N})$ & Dragon & Topological shape and size & 2D Atom Pairs & $\begin{array}{c}\text { Sum of topological distances } \\
\text { between N..N }\end{array}$ \\
\hline & P_VSA_i_4 & Dragon & $\begin{array}{l}\text { Topological shape and } \\
\text { ionization potential }\end{array}$ & P_VSA-like descriptor & $\begin{array}{l}\text { P_VSA-like on ionization } \\
\text { potential, bin } 4\end{array}$ \\
\hline & $\mathrm{R} 1 \mathrm{v}+$ & Dragon & 3D shape and size & GETAWAY descriptors & $\begin{array}{l}\mathrm{R} \text { maximal autocorrelation of lag } 1 / \\
\text { weighted by van der Waals volume }\end{array}$ \\
\hline & RTv+ & Dragon & 3D shape and size & GETAWAY descriptors & $\begin{array}{l}\mathrm{R} \text { maximal index/ weighted } \\
\text { by van der Waals volume }\end{array}$ \\
\hline & SM1_Dz(i) & Dragon & $\begin{array}{l}\text { Topological shape, size } \\
\text { and ionization potential }\end{array}$ & 2D matrix-based descriptors & $\begin{array}{c}\text { Spectral moment of order } 1 \text { from } \\
\text { Barysz matrix weighted } \\
\text { by ionization potential }\end{array}$ \\
\hline & PEOE_VSA-0 & MOE & Topological shape and electric state & Partial Charge Descriptors & $\begin{array}{l}\text { Sum of vi where qi is } \\
\text { in the range }[-0.05,0.00) \text {. }\end{array}$ \\
\hline \multirow[t]{5}{*}{$\mathrm{T}-\mathrm{N}$} & CATS3D_03_AA & Dragon & 3D shape and size & CATS 3D & $\begin{array}{l}\text { CATS3D Acceptor-Acceptor } \\
\text { BIN } 03(3.000-4.000 \AA)\end{array}$ \\
\hline & ATSC4s & Dragon & Topological shape and size & 2D autocorrelations & $\begin{array}{l}\text { Centred Broto-Moreau autocorrelation } \\
\text { of lag } 4 \text { weighted by I-state }\end{array}$ \\
\hline & E1s & Dragon & 3D shape and size & WHIM descriptors & $\begin{array}{l}\text { 1st component accessibility } \\
\text { directional WHIM index/ } \\
\text { weighted by I-state }\end{array}$ \\
\hline & $\mathrm{L} 2 \mathrm{i}$ & Dragon & $\begin{array}{l}\text { 3D shape, size and } \\
\text { ionization potential }\end{array}$ & WHIM descriptors & $\begin{array}{l}\text { 2nd component size directional } \\
\text { WHIM index/weighted } \\
\text { by ionization potential }\end{array}$ \\
\hline & std_dim2 & MOE & 3D shape and size & $\begin{array}{l}\text { Surface Area, Volume } \\
\text { and Shape Descriptors }\end{array}$ & $\begin{array}{l}\text { Standard dimension 2: the square } \\
\text { root of the second largest eigenvalue } \\
\text { of the covariance matrix of the } \\
\text { atomic oordinates. A standard } \\
\text { dimension is equivalent to the } \\
\text { standard eviation along a } \\
\text { principal component axis. }\end{array}$ \\
\hline
\end{tabular}

Computational analysis. QSAR analysis of cytotoxicity and tumor-specificity of eight 2-arylazolylchromones and twelve 2-triazolylchromones were next performed. Since significant correlation $(p<0.05)$ was found between cytotoxicity against tumor and normal cells and TS with 629, 59 and 481 chemical descriptors (data not shown), the top six chemical descriptors were chosen for QSAR analysis (Figures 4, 5 and 6 , and Table II).

The cytotoxicity of 20 compounds against OSCC cells was negatively correlated with descriptors SaaN (topological shape and electric state $)\left(\mathrm{r}^{2}=0.709, p<0.0001\right), \mathrm{P} \_$VSA_e_3 (topological shape and electric state) $\left(\mathrm{r}^{2}=0.667, p<0.0001\right)$, SlogP_VSA1 (topological size and lipophilicity) $\left(r^{2}=0.667\right.$, $p<0.0001)$, BCUT_PEOE_1 (topological shape and partial charges) $\left(\mathrm{r}^{2}=0.635, p<0.0001\right)$ and $\mathrm{T}(\mathrm{N} . . \mathrm{N})$ (topological shape and size $)\left(r^{2}=0.608, p=0.0001\right)$, but positively with $\mathrm{nBnz}$ (topological shape and size) $\left(\mathrm{r}^{2}=0.597, p=0.0001\right)$ (Figure 4).

The cytotoxicity of 20 compounds against human normal oral mesenchymal cells was negatively correlated with $\mathrm{T}(\mathrm{N} . . \mathrm{N})$ 

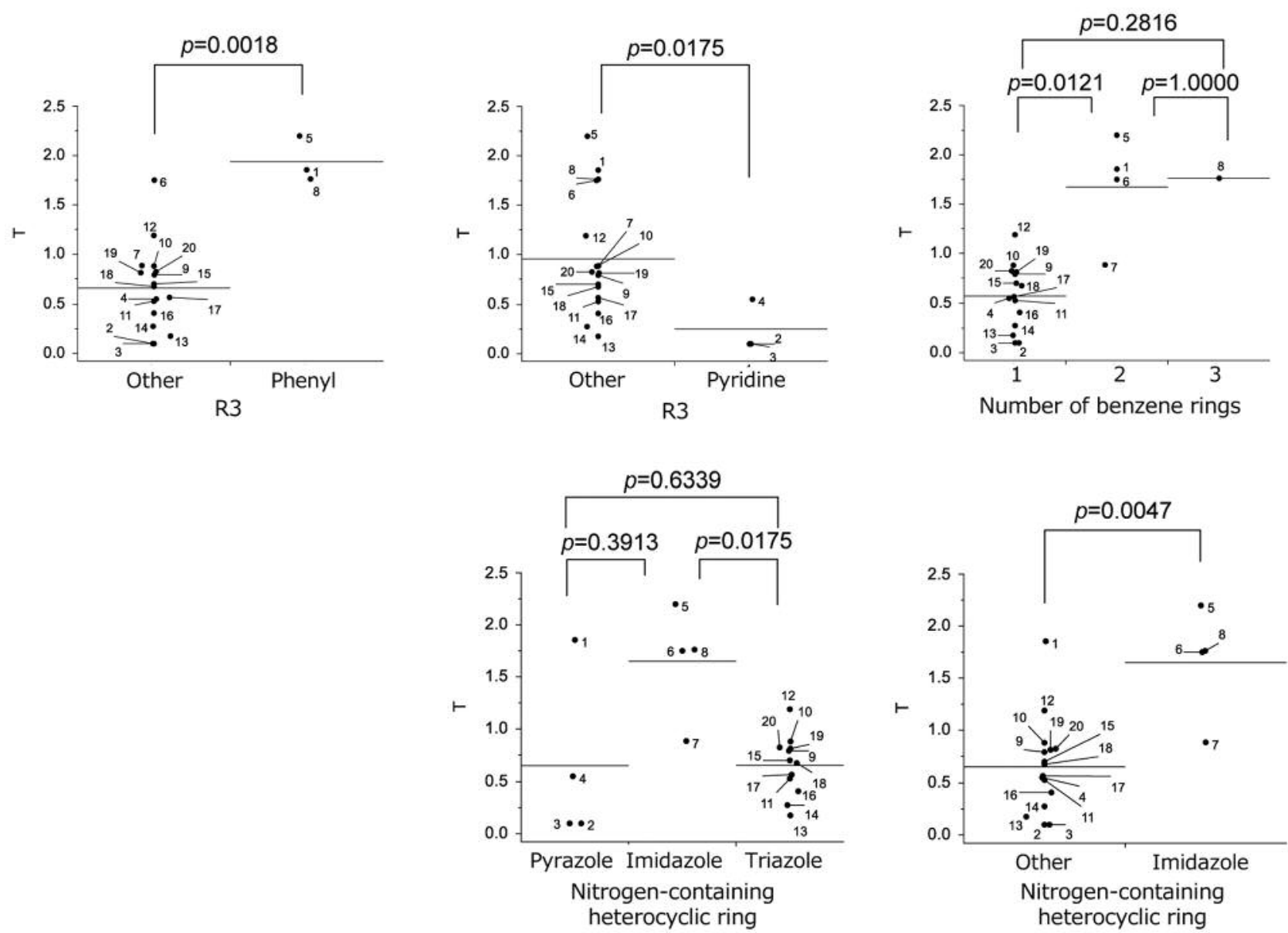

Figure 7. Correlation between $T$ and the presence of benzene, pyridine, pyrazole and imidazole rings. Statistical comparison between the means of two or three groups was performed by Wilcoxon exact test and Steel-Dwass test, respectively. The significance level was set at $p<0.05$.

(topological shape and size) $\left(\mathrm{r}^{2}=0.338, p=0.0072\right)$, P_VSA_i_4 (topological shape and ionization potential) $\left(\mathrm{r}^{2}=0.337\right.$, $p=0.0072)$, SM1_Dz(i) (topological shape, size and ionization potential) $\left(\mathrm{r}^{2}=0.330, p=0.0080\right)$ and PEOE_VSA-0 (topological shape and electric state) $\left(\mathrm{r}^{2}=0.325, p=0.0087\right)$, but positively with $\mathrm{R} 1 \mathrm{v}+(3 \mathrm{D}$ shape and size $)\left(\mathrm{r}^{2}=0.335, p=0.0075\right)$ and $\mathrm{RT}+$ (3D shape and size) $\left(\mathrm{r}^{2}=0.335, p=0.0075\right)$, (Figure 5).

The TS of 20 compounds was correlated with CATS3D_03_AA (3D shape and size) $\left(\mathrm{r}^{2}=0.608, p<0.0001\right)$, ATSC4s (topological shape and size) $\left(\mathrm{r}^{2}=0.589, p=0.0001\right)$, E1s (3D shape and size) $\left(r^{2}=0.564, p=0.0001\right)$, L2i (3D shape, size and ionization potential) $\left(\mathrm{r}^{2}=0.555, p=0.0002\right)$, std_dim2 (3D shape) $\left(\mathrm{r}^{2}=0.555, p=0.0002\right)$ and $\mathrm{L} 2 \mathrm{u}(3 \mathrm{D}$ shape, size) $\left(\mathrm{r}^{2}=0.550, p=0.0002\right)$ (Figure 6).

Functional group analysis. The cytotoxicity of 20 compounds against OSCC cell lines was increased when a phenyl group was at the $\mathrm{R} 3$ position $(p=0.0018)$ but was reduced when it was

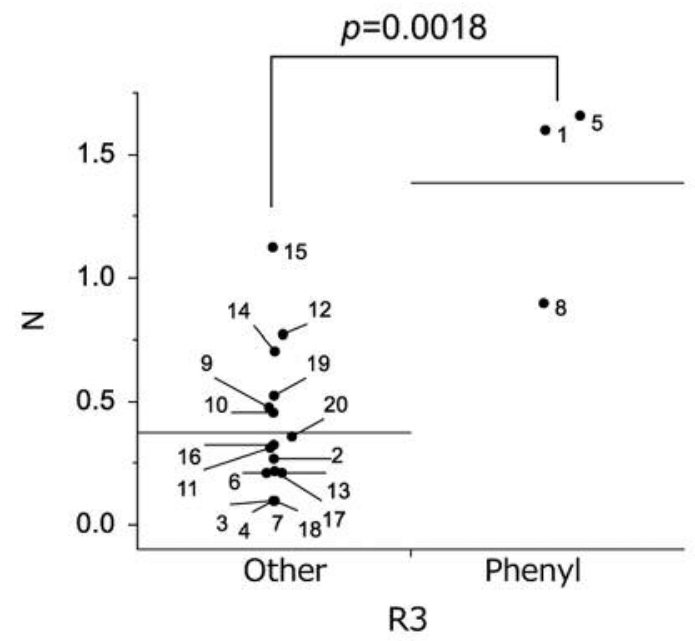

Figure 8. Correlation between $N$ and benzene ring. Statistical comparison between the means of two groups was performed by Wilcoxon exact test. The significance level was set at $p<0.05$. 

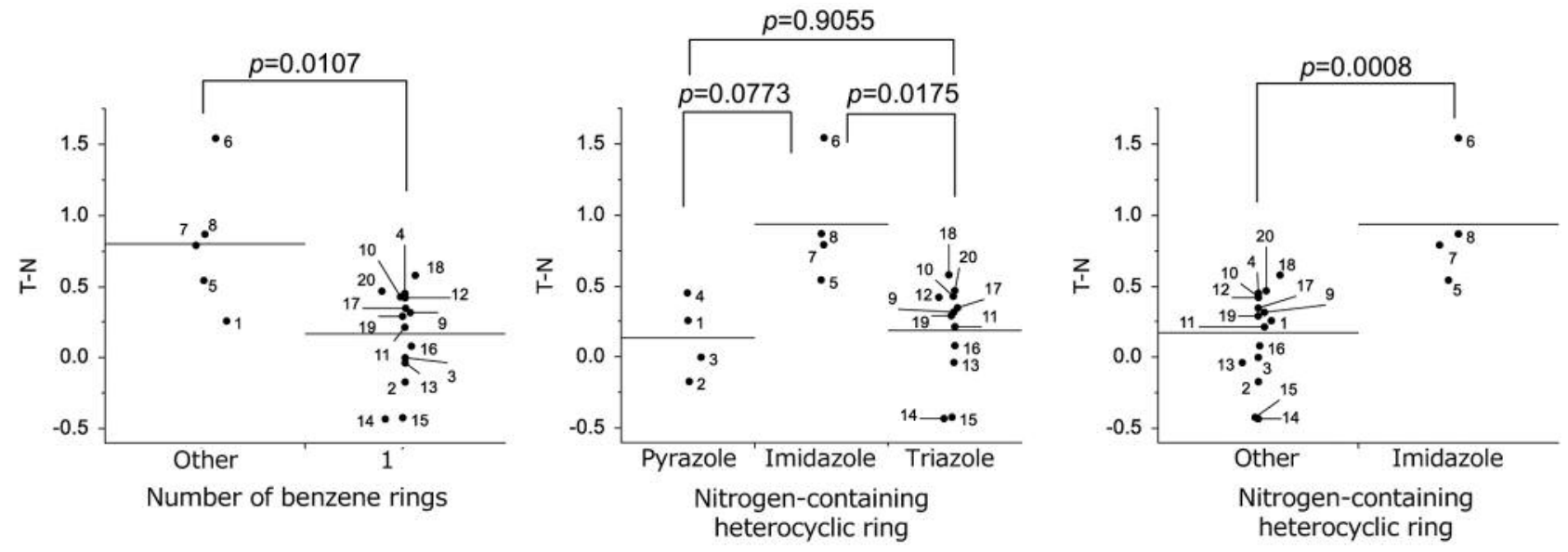

Figure 9. Correlation between T-N and benzene and imidazole ring. Statistical comparison between the means of two or three groups was performed by Wilcoxon exact test and Steel-Dwass test, respectively. The significance level was set at $p<0.05$.

replaced with pyridine $(p=0.0175)$. When the nitrogencontaining heterocyclic ring had imidazole rather than pyrazole or triazole, cytotoxicity was increased ( $p=0.0047$ ) (Figure 7).

The cytotoxicity of 20 compounds against normal oral cells was higher when a phenyl group was present at R3 $(p=0.0018)$ (Figure 8). The type of substituted groups and the presence or absence of halogen $(\mathrm{F}$ or $\mathrm{Cl}$ ) did not significantly affect cytotoxicity (not shown).

Tumor- specificity of 20 compounds was significantly increased by having more than two benzene rings and imidazole in the nitrogen-containing heterocyclic ring (Figure 9).

\section{Discussion}

The present study demonstrated that cytotoxicity of eight 2arylazolylchromones and twelve 2-triazolylchromones against tumor cell lines was significantly $(p<0.0001)$ correlated with topological shape, size, partial charge and lipophilicity (Figures 4). When benzene rather than pyridine was at position R3, higher cytotoxicity was produced (Figures 7 and 8).

Their tumor-specificity was also significantly correlated $(p<0.0002)$ with 3D shape, topological shape, size, ionization potential (Figure 6). When there were more than two aromatic rings in the molecule and imidazole ring in the nitrogen-containing heterocyclic ring, higher tumorspecificity was observed (Figure 9).

All eight 2-triazolylchromones showed much lower tumorspecificity (TS=0.6 2.6) (Table I), confirming our previous finding of low tumor-specificity of six 2-triazolylchromones 2-(1H-1,2,4-triazol-1-yl)-4H-1-benzopyran-4-one [4a], 7methoxy-2-(1H-1,2,4-triazol-1-yl)-4H-1-benzopyran-4-one [4b], 6-methoxy-2-(1H-1,2,4-triazol-1-yl)-4H-1-benzopyran4-one [4c], 2-(1H-1,2,3-triazol-1-yl)-4H-1-benzopyran-4-one [5a], 7-methoxy-2-(1H-1,2,3-triazol-1-yl)-4H-1-benzopyran4-one [5b], 6-methoxy-2-(1H-1,2,3-triazol-1-yl)-4H-1benzopyran-4-one [5c] TS=0.9-5)(15).

The present study also demonstrated that among the twenty compounds, [6] showed the highest tumor specificity (as shown by TS and PSE values) (Table I). Furthermore, the tumor-specificity of [6] $(\mathrm{TS}=21.2, \mathrm{PSE}=115.0)$ was comparable with that of 5-FU (TS=56.4, PSE=318.0) and doxorubicin $(\mathrm{TS}=12.4$; PSE=11689.5) (Table I). It should be noted that the TS value of [6] was higher than that of doxorubicin $(\mathrm{TS}=12.4)$. In contrast to positive control of actinomycin $\mathrm{D},[6]$ did not increase the $\mathrm{subG}_{1}$ cell population (a marker of apoptosis), but rather induced cytostatic growth inhibition, accumulation of cells in the $\mathrm{G}_{2}+\mathrm{M}$ phase (Figure 3). The possibility of inhibition of microtubule formation by [6] should be investigated. Further studies are needed to test the possibility that non-apoptotic cell death is related to the cytostatic growth inhibition rather than cell killing. [6] can be a lead compound for designing a new type of anticancer drugs.

\section{Conflicts of Interest}

The Authors confirm that there are no conflicts of interest associated with this publication and there has been no significant financial support for this work that could have influenced its outcome.

\section{Authors' Contributions}

J.N. and Y.U. performed the QSAR analysis. HX.S. and H.S. performed the cytotoxicity assay. N.S., N.Y., K.T. and Y.S. synthesized 20 test compounds. K.B., M.T. and A. T. performed the cell cycle analysis. Y.U., H.S. and Y.S. authored or reviewed drafts of the article. 


\section{Acknowledgements}

This work was partially supported by KAKENHI from the Japan Society for the Promotion of Science (JSPS) (15K08111, 16K11519).

\section{References}

1 Sakagami H: Biological activities and possible dental application of three major groups of polyphenols. Review. J Pharmacol Sci 126(2): 92-106, 2014. PMID: 25263279.

2 Gaspar A, Matos MJ, Garrido J, Uriarte E and Borges F: Chromone: a valid scaffold in medicinal chemistry. Chem Rev 114(9): 49604992, 2014. PMID: 24555663. DOI: $10.1021 / \mathrm{cr} 400265 \mathrm{z}$

3 Gaspar A, Mohabbati M, Cagide F, Razzaghi-Asl N, Miri R, Firuzi $\mathrm{O}$ and Borges F: Searching for new cytotoxic agents based on chromen-4-one and chromane-2,4-dione scaffolds. Res Pharm Sci 14(1): 74-83, 2019. PMID: 30936935. DOI: 10.4103/1735-5362.251855.

4 Al-Oudat BA, Alqudah MA, Audat SA, Al-Balas QA, El-Elimat T, Hassan MA, Frhat IN and Azaizeh MM: Design, synthesis, and biologic evaluation of novel chrysin derivatives as cytotoxic agents and caspase-3/7 activators. Drug Des Devel Ther 13: 423433, 2019. PMID: 30774307. DOI: 10.2147/DDDT.S189476

5 Kozłowska J, Grela E, Baczyńska D, Grabowiecka A and Anioł M: Novel $O$-alkyl derivatives of naringenin and their oximes with antimicrobial and anticancer activity. Molecules 24(4): pii: E679, 2019. PMID: 30769816. DOI: 10.3390/molecules24040679.

6 Sakagami H, Watanabe T, Hoshino T, Suda N, Mori K, Yasui T, Yamauchi N, Kashiwagi H, Gomi T, Oizumi T, Nagai J, Uesawa Y, Takao K and Sugita Y: Recent progress of basic studies of natural products and their dental application. Review. Medicines (Basel) 6(1): pii: E4, 2018. PMID: 30585249. DOI: 10.3390/ medicines6010004

7 Sugita Y, Takao K, Uesawa Y and Sakagami H: Search for new type of anticancer drugs with high tumor specificity and less keratinocyte toxicity. Review. Anticancer Res 37(11): 59195924, 2017. PMID: 29061770.

8 Shimada C, Uesawa Y, Ishii-Nozawa R, Ishihara M, Kagaya H, Kanamto T, Terakubo S, Nakashima H, Takao K, Sugita Y and Sakagami H: Quantitative structure-cytotoxicity relationship of 3-styrylchromones. Anticancer Res 34: 5405-5412, 2014. PMID: 25275035.

9 Uesawa Y, Sakagami H, Ishihara M, Kagaya H, Kanamoto T, Terakubo S, Nakashima H, Yahagi H, Takao K and Sugita Y: Quantitative structure-cytotoxicity relationship of 3-styryl-2Hchromenes. Anticancer Res 35: 5299-5308, 2015. PMID: 26408690.
10 Sakagami H, Okudaira N, Uesawa Y, Takao K, Kagaya H and Sugita Y: Quantitative structure-cytotoxicity relationship of 2azolylchromones. Anticancer Res 38(2): 763-770, 2018. PMID: 29374700. DOI: 10.21873 /anticanres.12282

11 Sakagami H, Okudaira N, Masuda Y, Amano O, Yokose S, Kanda $Y$, Suguro M, Natori T, Oizumi $H$ and Oizumi T: Induction of apoptosis in human oral keratinocyte by doxorubicin. Anticancer Res 37(3): 1023-1029, 2017. PMID: 28314260. DOI: 10.21873/anticanres.11412

12 Takao K, Saito T, Chikuda D and Sugita Y: 2-Azolylchromone derivatives as potent and selective inhibitors of monoamine oxidases A and B. Chem Pharm Bull (Tokyo). 64(10): 14991504, 2016. PMID: 27725503.

13 Kantoh K, Ono M, Nakamura Y, Nakamura Y, Hashimoto K, Sakagami $\mathrm{H}$ and Wakabayashi $\mathrm{H}$ : Hormetic and anti-radiation effects of tropolone-related compounds. In Vivo 24: 843-852, 2010. PMID: 21164042.

14 Horikoshi M, Kimura Y, Nagura H, Ono T and Ito H: A new human cell line derived from human carcinoma of the gingiva. I. Its establishment and morphological studies. Jpn J Oral Maxillofac Surg 20: 100-106, 1974. PMID: 4549822.

15 Nagai J, Shi H, Kubota Y, Bandow K, Okudaira N, Uesawa Y, Sakagami H, Tomomura M, Tomomura A, Takao K and Sugita Y: Quantitative structure-cytotoxicity relationship of pyrano[4,3b]chromones. Anticancer Res 38(8): 4449-4457, 2018. PMID: 30061209. DOI: 10.21873 /anticanres.12747

16 MarvinSketch 18.10.0. Available at: http://www.chemaxon.com (Last accessed on 16th October 2019)

17 CORINA Classic. Available at: https://www.mn-am.com/ products/corina (Last accessed on 16th October 2019)

18 MOE2019.0101, Chemical Computing Group. Available at: https://www.chemcomp.com/Products.htm (Last accessed on 16th October 2019)

19 Dragon 7. Available at: https://chm.kode-solutions.net/products_ dragon_descriptors.php (Last accessed on 16th October 2019)

20 JMP®. Available at: https://www.jmp.com/en_us/home.html (Last accessed on 16th October 2019). 